\title{
Effect of inactivating mutations on phosphorylation and internalization of the human $\mathrm{VPAC}_{2}$ receptor
}

\author{
Ingrid Langer, Christelle Langlet and Patrick Robberecht \\ Department of Biological Chemistry and Nutrition, Faculty of Medicine, Université Libre de Bruxelles, Bat GE, CP 611, 808 Route de Lennik, B-1070 Brussels, Belgium
}

(Requests for offprints should be addressed to I Langer; Email: ilanger@ulb.ac.be)

\begin{abstract}
The $\mathrm{VPAC}_{2}$ receptor, as all members of the G-protein-coupled receptor (GPCR)-B family, has two highly conserved motifs in the third intracellular $\left(\mathrm{IC}_{3}\right)$ loop: a lysine and a leucine located at the amino-terminus and two basic residues separated by a leucine and an alanine at the carboxyl-terminus. This study evaluates the involvement of those conserved amino acid sequences in $\mathrm{VPAC}_{2}$ signal transduction and regulation. The residues were mutated into alanine and mutants were expressed in Chinese hamster ovary $(\mathrm{CHO})$ cells stably transfected with $\mathrm{G} \alpha 16$ and aequorin. Mutation of L310 reduced efficacy of vasoactive intestinal polypeptide (VIP) to stimulate adenylate cyclase activity through Gas coupling by $75 \%$, without affecting VIP capability to stimulate an increase in $\left[\mathrm{Ca}^{2+}\right]_{\mathrm{i}}$ through $\mathrm{G} \alpha 16$ coupling. Mutation of R325 and, to a lesser extend, K328 reduced VIP efficacy to stimulate [Ca $\left.{ }^{2+}\right]_{i}$ increase and VIP potency to stimulate adenylate cyclase. The combination of mutations of both amino- and carboxyl-terminus located conserved motifs of the $\mathrm{IC}_{3}$ loop generates an inactive receptor with respect to $[\mathrm{Ca}+]_{\mathrm{i}}$ increase and adenylate cyclase activation, but also with respect to receptor phosphorylation and internalization that were indeed directly correlated with the potency of inactivation of the receptors.

The amino-terminus of the $\mathrm{VPAC}_{2}$ receptor $\mathrm{IC}_{3}$ loop is thus involved in adenylate cyclase activation and the carboxyl-terminus of the $\mathrm{IC}_{3}$ loop participates in both $\mathrm{G} \alpha$ s and $\mathrm{G} \alpha 16$ coupling. The mutations studied also reduced both receptor phosphorylation and internalization in a manner that appeared directly linked to the alteration of $\mathrm{G} \alpha \mathrm{s}$ and Ga16 coupling.
\end{abstract}

Journal of Molecular Endocrinology (2005) 34, 405-414

\section{Introduction}

Vasoactive intestinal polypeptide (VIP) is a neuropeptide that contributes to regulation of intestinal secretion and motility, of exocrine and endocrine secretions (Fahrenkrug 1993), and to homeostasis of the immune system (Gomariz et al. 2001). The effects of VIP are mediated through interaction with two receptor subclasses named $\mathrm{VPAC}_{1}$ and $\mathrm{VPAC}_{2}$ receptors (Harmar et al. 1998). These receptors are members of the G-protein-coupled receptor (GPCR)-B family, that also includes the receptors for PACAP, secretin, glucagon, GLP-1, calcitonin, parathyroid hormone and GRF, and are preferentially coupled to Gas protein that stimulates adenylate cyclase activity and induces cyclic AMP (cAMP) increase (Harmar et al. 1998). We previously demonstrated that both $\mathrm{VPAC}_{1}$ and $\mathrm{VPAC}_{2}$ receptors are also able to couple to the $\mathrm{IP}_{3} /[\mathrm{Ca} 2+]_{\mathrm{i}}$ pathway (Langer et al. 2001). In CHO cells expressing a comparable density of recombinant receptors, VIP induced $\left[\mathrm{Ca}^{2+}\right]_{\mathrm{i}}$ increase is more efficient in $\mathrm{VPAC}_{1}$ than in $\mathrm{VPAC}_{2}$ receptor-expressing cells (Langer et al. 2001). While $\mathrm{VPAC}_{1}$ receptor-mediated response can be attributed to both Gaq and Gai coupling (Langer et al.
2002). Efficient $\left[\mathrm{Ca}^{2+}\right]_{\mathrm{i}}$ increase following $\mathrm{VPAC}_{2}$ receptor activation can be achieved in the presence of Ga16, a member of the Gaq family that allows the coupling of a wide variety of receptors to phospholipase G (Langer et al. 2001) and whose expression is restricted to hematopoietic and immune cells that express functional $\mathrm{VPAC}_{2}$ receptors (Langer et al. 2001).

The study of a wide variety of chimeric or mutated seven transmembrane (TM) receptors demonstrated that the second $\left(\mathrm{IC}_{2}\right)$ and third intracellular $\left(\mathrm{IC}_{3}\right)$ loops, and to a lesser extent the proximal part of the carboxylterminal tail, can be directly involved in G-protein/ receptor interactions (Wess 1997). However, the diversity of sequences and loop sizes, even among related receptors, has made the identification of a specific set of amino acid residues to define the coupling profile difficult. In the present study we investigated the contribution of two highly conserved amino acid motifs among all members of the GPCR-B family located at the junction of $\mathrm{TM}_{5}$ and $\mathrm{IC}_{3}$ loop $\left(\mathrm{K}^{309}-\mathrm{L}^{310}-\mathrm{T}^{311}\right)$ and of $\mathrm{IC}_{3}$ loop and $\mathrm{TM}_{6}\left(\mathrm{R}^{325}\right.$ and $\left.\mathrm{K}^{328}\right)$, in human recombinant $\mathrm{VPAC}_{2}$ receptors expressed in Chinese hamster ovary $(\mathrm{CHO})$ cells. Like most GPCRs, $\mathrm{VPAC}_{2}$ receptor was reported to be rapidly phosphorylated, 
desensitized and internalized after agonist exposure (McDonald et al. 1998). Since receptor activation is also an important determinant of the agonist-induced receptor phosphorylation and internalization and as the $\mathrm{IC}_{3}$ loop is also an important domain for the binding of arrestin after receptor phosphorylation (Ferguson 2001, Perry \& Lefkowitz 2002), we evaluated the effect of mutations that impair $\mathrm{VPAC}_{2}$ receptor coupling to signalling pathway on receptor regulation. This study revealed that: 1) mutations in $\mathrm{IC}_{3}$ that affect the proximal residues significantly reduce VIP-induced adenylate cyclase activation (from 70 to $85 \%$ ) without affecting $\mathrm{VPAC}_{2}$ receptor ability to couple to the $\mathrm{IP}_{3} /[\mathrm{Ca} 2+]_{\mathrm{i}}$ pathway through Ga16 interaction; 2) mutations that affect the distal residues affect both VIP-mediated cAMP and $\left[\mathrm{Ca}^{2+}\right]_{\mathrm{i}}$ increase; 3) combination of mutations in both domains inactivates $\mathrm{VPAC}_{2}$ receptor and 4) G-protein coupling-inactivating mutations also reduced both receptor phosphorylation and internalization in a manner that appeared directly linked to the alteration of Gas and Ga16 coupling.

\section{Materials and methods}

\section{Construction and expression of $\mathrm{VPAC}_{2}$ mutant receptors}

The cell line expressing $\mathrm{VPAC}_{2}$ receptor has been detailed in previous a publication (Langer et al. 2001). Generation of mutated receptors was achieved using the QuikChange Site-Directed Mutagenesis kit (Stratagene, La Jolla, CA, USA) according to the manufacturer's instructions as described (Langer et al. 2002). Confirmation of the expected mutation was achieved by DNA sequencing on an ABI automated sequencing apparatus, using the BigDye Terminator Sequencing Prism Kit from ABI (Perkin-Elmer, CA, USA). Following DNA amplification using a midiprep endotoxin-free kit (Stratagene), the complete nucleotide sequence of the receptor coding region was verified by DNA sequencing. $20 \mu \mathrm{g}$ of receptor coding region was transfected by electroporation into the CHO cell line expressing aequorin and Ga16 (kindly provided by Vincent Dupriez, Euroscreen SA, Brussels, Belgium) as described previously (Langer et al. 2001). Selection was carried out in culture medium $[50 \%$ HamF12; 50\% DMEM; 10\% fetal calf serum; 1\% Penicillin $(10 \mathrm{mU} / \mathrm{ml}) ; 1 \%$ Streptomycin $(10 \mu \mathrm{g} / \mathrm{ml}) ; 1 \%$ L-Glutamine (200 mM), Life Technologies Ltd, Paisley, UK.], supplemented with $600 \mu \mathrm{g}$ Geneticin (G418)/ml culture medium. After 10 to 15 days of selection, isolated colonies were transferred to 24-well plates and grown until confluence, trypsinized and further expanded in 6 -well plates, from which cells were scraped and membranes prepared for identification of receptor expressing clones by an adenylate cyclase activity assay in presence of $1 \mu \mathrm{M}$ VIP. Selection of KLT-AAA R325A-K328A and $\triangle \mathrm{KLT}$ R325A-K328A mutants was carried out by binding assay with $\left[{ }^{125} \mathrm{I}\right]$-Ro 25-1553 (see below).

\section{Membrane preparation}

Membranes were prepared from scraped cells lysed in $1 \mathrm{mM} \mathrm{NaHCO} 3$ by immediate freezing in liquid nitrogen. After thawing, the lysate was first centrifuged at $4{ }^{\circ} \mathrm{C}$ for $10 \mathrm{~min}$ at $400 \mathrm{~g}$ and the supernatant was further centrifuged at $20000 \boldsymbol{g}$ for $10 \mathrm{~min}$. The resulting pellet, resuspended in $1 \mathrm{mM} \mathrm{NaHCO} 3$, was used immediately as a crude membrane fraction.

\section{Adenylate cyclase activation assay}

Adenylate cyclase activity was determined by the procedure of Salomon et al. (1974), as described previously. Membrane proteins $(3-15 \mu \mathrm{g})$ were incubated in a total volume of $60 \mu \mathrm{l}$ containing $0.5 \mathrm{mM}$ $\left[\alpha^{32} \mathrm{P}\right]-\mathrm{ATP}, 10 \mu \mathrm{M} \quad \mathrm{GTP}, 5 \mathrm{mM} \quad \mathrm{MgCl}_{2}, 0.5 \mathrm{mM}$ EGTA, $1 \mathrm{mM}$ cAMP, $1 \mathrm{mM}$ theophylline, $10 \mathrm{mM}$ phospho(enol)pyruvate, $30 \mu \mathrm{g} / \mathrm{ml}$ pyruvate kinase and $30 \mathrm{mM}$ Tris- $\mathrm{HCl}$ at a final $\mathrm{pH}$ of $7 \cdot 8$. The reaction was initiated by the addition of the membranes and was terminated after $15 \mathrm{~min}$ incubation at $37^{\circ} \mathrm{C}$ by adding $0.5 \mathrm{ml}$ of a $0.5 \%$ sodium dodecyl-sulfate solution containing $0.5 \mathrm{mM}$ ATP, $0.5 \mathrm{mM}$ cAMP and 20000 c.p.m. $\left[{ }^{3} \mathrm{H}\right]$-cAMP. cAMP was separated from ATP by two successive chromatographies on Dowex 50W x 8 and neutral alumina.

\section{Binding studies}

Binding studies were performed by using the selective

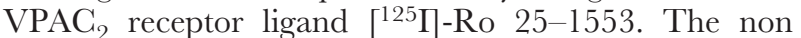
specific binding was defined as residual binding in the presence of $1 \mu \mathrm{M}$ unlabeled Ro $25-1553$. $\left[{ }^{125} \mathrm{I}\right]$-Ro 25-1553 was preferred for quantification of receptors as the specific binding and the ratio between total and non specific binding was higher than with $\left[{ }^{125} \Gamma\right]$-VIP. Binding was performed for $30 \mathrm{~min}$ at $23{ }^{\circ} \mathrm{C}$ in a total volume of $120 \mu \mathrm{l}$ containing $20 \mathrm{mM}$ Tris-maleate, $2 \mathrm{mM} \mathrm{MgCl}{ }_{2}, 0 \cdot 1 \mathrm{mg} / \mathrm{ml}$ bacitracin, $1 \%$ BSA (pH 7.4) buffer. 3-30 $\mu \mathrm{g}$ of protein was used per assay. Bound and free radioactivity were separated by filtration through glass-fiber GF/C filters presoaked for $24 \mathrm{~h}$ in $0.01 \%$ polyethyleneimine and rinsed three times with a $20 \mathrm{mM}$ (pH 7.4) sodium phosphate buffer containing $0 \cdot 8 \%$ BSA. The binding sites density was estimated by analysis of homologous competition curves assuming that the labeled and unlabeled ligands had the same affinity for the receptors.

\section{$\left[\mathrm{Ca}^{2+}\right]_{\mathrm{i}}$ increase assay}

$\left[\mathrm{Ca}^{2+}\right]_{\mathrm{i}}$ increase was measured by a functional assay based on the luminescence of mitochondrial aequorin/ 
coelenterazine following $[\mathrm{Ca} 2+]_{\mathrm{i}}$ increase as described previously (Brini et al. 1995, Stables et al. 1997). Briefly, cells were collected from plates with PBS containing $5 \mathrm{mM}$ EDTA, pelleted and resuspended at $5 \cdot 10^{6}$ cells $/ \mathrm{ml}$ in DMEM-F12 medium supplemented with $0.5 \%$ BSA, incubated with $5 \mu \mathrm{M}$ coelenterazine $\mathrm{H}$ (Molecular Probes, Eugene, OR, USA) for $3 \mathrm{~h}$ at room temperature under light agitation. Cells were then diluted at a concentration of $5 \cdot 10^{5}$ cells $/ \mathrm{ml}$ and incubated for one more hour. $50 \mu \mathrm{l}$ of cell suspension was added to agonists diluted in a volume of $50 \mu \mathrm{l}$ DMEM-F12. $[\mathrm{Ca} 2+]_{\mathrm{i}}$ increase was evaluated by measuring for $20 \mathrm{~s}$ the luminescent signal (integration of area under the curve) resulting from the activation of the aequorin-coelenterazine complex using a Victor luminometer (Perkin Elmer, Wellesley, MA, USA). The data were normalized for basal (0\%, background removal) and maximal luminescence $(100 \%)$ corresponding to the signal measured following exposure to $50 \mu \mathrm{M}$ of digitonin.

\section{Genetic immunization and generation of monoclonal antibody $(\mathrm{mAb})$ for $\mathrm{VPAC}_{2}$ receptor identification}

Six week old Balb/c female mice were anaesthetized by injections of $6-10 \mathrm{mg} / \mathrm{kg}$ ketamin $\mathrm{HCl}$ and $0.1 \mathrm{ml} / \mathrm{kg}$ Rompum. The anterior tibialis muscle of each leg was injected at day 0 with $100 \mu \mathrm{l}$ of $10 \mathrm{mM}$ cardiotoxin (Latoxan, Rosans, France) and 5 days later with $50 \mu \mathrm{g}$ of the plasmid construct in a final volume of $100 \mu \mathrm{l} 0 \cdot 09 \%$ $\mathrm{NaCl}$. Injections were repeated 3 and 6 weeks thereafter. Blood samples were collected from retro-ocular puncture 7 weeks after the initial immunization and serum tested by FACS and Western Blotting for the presence of antibodies against $\mathrm{VPAC}_{2}$ receptor. The mouse selected for $\mathrm{mAb}$ production, was boosted by i.v. injection of $10^{6}$ $\mathrm{CHO}$ cells expressing the human $\mathrm{VPAC}_{2}$ receptor resuspended in $100 \mu \mathrm{l}$ saline solution. Three days later, splenocytes were fused with SP2O, a non-secreting myeloma cell line, at a 3:1 ratio in presence of polyethylene glycol. Fused cells were then delivered into 96-well plates and selected with $100 \mu \mathrm{M}$ hypoxantine, $400 \mu \mathrm{M}$ aminopterine and $16 \mu \mathrm{M}$ thymidine. Irradiated macrophages from mouse peritoneum were also added to supply cytokines and growth factors. After 10 days, culture supernatants were screened by FACS (see below) and the cells producing antibodies cloned by dilution. The monoclonal antibody selected ( $\mathrm{mAb} \mathrm{VPAC}_{2}$ ) was purified using ImmunoPure IgG Purification kit (Pierce, Rockford, IL, USA). Using the mouse $\mathrm{mAb}$ isotyping kit (Isotrip, Roche) we established that it was of the IgG 2a subtype.

\section{Immunoprecipitation and determination of receptor phosphorylation levels}

Cells were cultured in phosphate-free DMEM medium for $16 \mathrm{~h}$ and then incubated for $2 \mathrm{~h}$ at $37^{\circ} \mathrm{C}$ in the same medium containing $200 \mu \mathrm{Ci}$ acid-free $\left[{ }^{32} \mathrm{P}\right]$ orthophosphate. At the end of this labelling period agonist was added. When kinase inhibitors were tested, they were added $2 \mathrm{~h}$ prior to agonist addition. After agonist exposure, cells were washed three times with ice-cold buffer consisting of $10 \mathrm{mM}$ HEPES, $4.2 \mathrm{mM}$ $\mathrm{NaHCO}_{3}, 11.7 \mathrm{mM}$ glucose, $1.2 \mathrm{mM} \mathrm{MgSO}$, $4.7 \mathrm{mM}$ $\mathrm{KCl}, 118 \mathrm{mM} \mathrm{NaCl}$ and $1.3 \mathrm{mM} \mathrm{CaCl}_{2}, \mathrm{pH} 7 \cdot 4$, and subsequently lysed in $1 \mathrm{ml}$ of a buffer consisting of $20 \mathrm{mM}$ Tris, $100 \mathrm{mM}\left(\mathrm{NH}_{4}\right)_{2} \mathrm{SO}_{4}$ and $10 \%$ glycerol, $\mathrm{pH}$ 7.5. The cell lysate was centrifuged at $600 \boldsymbol{g}$ at $4{ }^{\circ} \mathrm{C}$ for $10 \mathrm{~min}$ and the supernatant centrifuged at $19000 \mathrm{~g}$ for $30 \mathrm{~min}$. The resulting pellet was resuspended in the same buffer containing $1 \%$ dodecylmaltoside and solubilized for $45 \mathrm{~min}$ at $4{ }^{\circ} \mathrm{C}$. The remaining insoluble material was eliminated by a further centrifugation. The supernatant was added to $50 \mu \mathrm{l}$ of a $10 \%$ protein A sepharose suspension previously coated during $2 \mathrm{~h}$ with $2 \mu \mathrm{g}$ of purified monoclonal antibody. After $150 \mathrm{~min}$ incubation under light agitation at $4{ }^{\circ} \mathrm{C}$, the sepharose beads were separated by centrifugation and washed successively with the concentrated lysis buffer, then with a two fold diluted buffer and finally with water. The final beads pellet was resuspended in a buffer consisting of $125 \mathrm{mM}$ Tris, $10 \% \beta$-mercaptoethanol, $4 \%$ SDS, 20\% glycerol and $0.02 \%$ bromophenol blue $\mathrm{pH}, 6 \cdot 8$. After heating at $60{ }^{\circ} \mathrm{C}$ for $10 \mathrm{~min}$, the samples were resolved by SDS page using $10 \%$ gel. The gel was fixed, dried and the phosphorylated bands detected and quantified by phosphoimaging.

\section{Receptor internalization}

Receptor internalization was defined as the percentage of cell surface receptors that were no longer accessible to the $\mathrm{mAb}$, after agonist exposure. Cells expressing $\mathrm{VPAC}_{2}$ or mutated receptors were incubated with $1 \mu \mathrm{M}$ VIP for $20 \mathrm{~min}$ at $37^{\circ} \mathrm{C}$. After washing 3 times with ice-cold PBS, cells were detached from the plates using a $5 \mathrm{mM}$ EDTA/EGTA PBS solution, harvested by centrifugation $\left(500 \boldsymbol{g}, 4^{\circ} \mathrm{C}, 4 \mathrm{~min}\right.$ ), washed once with PBS solution and resuspended at density of $3 \cdot 10^{5}$ cells/assay in $100 \mu \mathrm{l}$ PBS-BSA $0 \cdot 1 \%$, containing $0 \cdot 1 \mu \mathrm{g}$ purified anti-VPAC ${ }_{2}$ receptor $\mathrm{mAb}$. After $30 \mathrm{~min}$ incubation at $4{ }^{\circ} \mathrm{C}$, the cells were washed with PBS-BSA $0 \cdot 1 \%$ and then incubated with FITC-conjugated- $\gamma$-chain-specific goat anti-mouse IgG (Sigma Chemicals) for $30 \mathrm{~min}$ on ice in the dark. The labelled cells were washed and resuspended in $250 \mu \mathrm{l}$ PBS-BSA $0 \cdot 1 \%$. The fluorescence level was analyzed using a FACScalibur (Becton Dickinson, Franklin Lanes, NJ, USA) and the data processed using the cell quest software (Becton Dickinson, Franklin Lanes, NJ, USA). Basal fluorescence was determined from a sample of untransfected CHO cells. Propidium iodide $(10 \mu \mathrm{g} / \mathrm{ml})$ was used to exclude debris and dead cells from our analysis. 


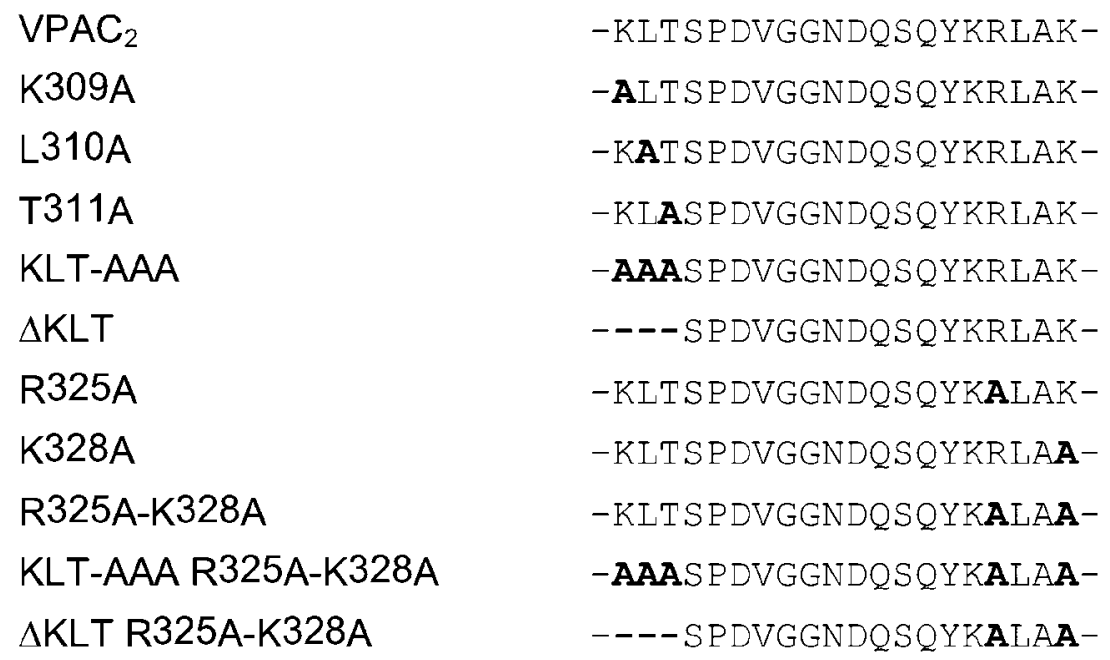

Figure 1 Amino acid sequences of $I_{3}$ loop of $\mathrm{VPAC}_{2}$ wild type and mutated receptors.

\section{Data analysis}

All competition curves, dose-response curves, $\mathrm{IC}_{50}$ and $\mathrm{EG}_{50}$ values were calculated using non linear regression (GraphPad Prism software, San Diego, CA, USA). Statistical analyses were performed with the same software.

\section{Results}

\section{Binding studies}

Receptor density was evaluated by $\left[{ }^{125} \Pi\right]$-Ro $25-$ $1553 /$ Ro 25-1553 binding studies. This molecule, a VIP analogue with a lactam bridge in the carboxyl-terminus was developed first as a potent long-acting bronchodilator (O'Donnell et al. 2004). It was later found to be a selective agonist that preferentially recognizes $\mathrm{VPAC}_{2}$ to $\mathrm{VPAC}_{1}$ receptor and a had higher affinity for $\mathrm{VPAC}_{2}$ receptor than VIP (Gourlet et al. 1997). When iodinated it also appeared to be a better ligand than iodinated VIP to label the $\mathrm{VPAC}_{2}$ receptors, as the ratio total binding/non specific binding was higher for iodinated Ro 25-1553. All the mutants (Fig. 1) were expressed at the membrane. Screening of several cell clones was performed to select a material expressing a comparable density of sites and therefore an easier comparison of the data (Table 1). However four clones studied (KLT-AAA, $\triangle$ KLT, KLT-AAA R325A-K328A and $\triangle$ KLT R325A$\mathrm{K} 328 \mathrm{~A}$ ) expressed a 6 - to 12 -fold higher receptor density than those expressing the wild type receptor. VIP IC $_{50}$ values were not significantly different from the wild type receptor value $(3 \mathrm{nM})$ for the $\mathrm{K} 309 \mathrm{~A}$ and $\mathrm{T} 311 \mathrm{~A}$ mutants. For all other mutants, VIP $\mathrm{IC}_{50}$ values were significantly higher (between 10 and $50 \mathrm{nM}$, see Table 1 and Fig. 2). The effect of GTP was also evaluated. In competition binding assays GTP inhibited about $30 \%$ of tracer binding except for KLT-AAA, $\triangle$ KLT, R325AK328A, KLT-AAA R325A-K328A and $\Delta$ KLT R325AK328A mutants that display a lower tracer binding inhibition (Table 1).

\section{Adenylate cyclase activation}

VIP dose-effect curves of adenylate cyclase stimulation were performed on each clone. VIP $\mathrm{EG}_{50}$ values for $\mathrm{K} 309 \mathrm{~A}$ and T311A mutants were identical to the wild type receptor value $(2-3 \mathrm{nM})$. L310A mutant displayed a moderate decrease of VIP potency $(10 \mathrm{nM})$ and efficacy $(70 \%)$ to stimulate cAMP production. When deleting or mutating the $\mathrm{K}^{309}-\mathrm{L}^{310}-\mathrm{T}^{311}$ sequence into alanine, VIP efficacy (but not potency) was slightly further reduced. However KLT-AAA and $\triangle$ KLT expressing cell lines had a significant higher receptor density (6- to 9-fold), and it is therefore possible that the effect of those combined modifications and the potential contribution of $\mathrm{K}^{309}$ and $\mathrm{T}^{311}$ were underestimated. In the same line, the discrepancy between VIP $\mathrm{EG}_{50}$ and VIP $\mathrm{IC}_{50}$ values of the KLT-AAA mutant could be explained by spare receptors. Mutation of $\mathrm{R}^{325}$ or $\mathrm{K}^{328}$ into alanine reduced VIP potency (about 15-fold) without affecting the maximal stimulatory effect. Combining those mutations (R325A-K328A) dramatically decreased both VIP efficacy $(90 \%)$ and potency (25-fold). cAMP production could not be detected for the KLT-AAA R325A-K328A and $\Delta$ KLT R325A-K328A mutants despite the expression of a very high receptor density of $37 \cdot 7$ and $26 \cdot 1 \mathrm{pmole} / \mathrm{mg}$ protein respectively (Table 1 and Fig. 2). 
Table 1 Summary of binding and functional studies performed on wild type and mutated VPAC $_{2}$ receptors

\begin{tabular}{|c|c|c|c|c|c|c|c|}
\hline & \multirow{2}{*}{$\begin{array}{l}\text { Receptor density } \\
\text { (pmole/mg protein) }\end{array}$} & \multicolumn{2}{|l|}{ Binding } & \multicolumn{2}{|l|}{ CAMP } & \multicolumn{2}{|l|}{$\left[\mathrm{Ca}^{2+}\right]$} \\
\hline & & $\mathrm{IC}_{50}(\mathrm{nM})$ & GTP effect§ & EC50 (nM) & Emax & EC50 (nM) & $\operatorname{Emax}^{\circ}$ \\
\hline $\mathrm{VPAC}_{2}$ & $3 \cdot 0 \pm 0.6$ & $2 \cdot 6 \pm 0 \cdot 3$ & $27 \pm 2$ & $2 \cdot 2 \pm 0.5$ & $228 \pm 16$ & $120 \pm 16$ & $82 \pm 2$ \\
\hline \multicolumn{8}{|c|}{ Mutation in $\mathrm{N}$-terminus of $\mathrm{IC}_{3}$ loop } \\
\hline K309A & $4.0 \pm 0.4$ & $4 \cdot 0 \pm 0 \cdot 6$ & $30 \pm 3$ & $3.3 \pm 0.3$ & $202 \pm 9$ & $90 \pm 14$ & $70 \pm 4$ \\
\hline L310A & $5 \cdot 8 \pm 0 \cdot 3^{*}$ & $11 \cdot 2 \pm 0 \cdot 8^{*}$ & $29 \pm 3$ & $10 \cdot 0 \pm 0 \cdot 9^{*}$ & $60 \pm 7^{*}$ & $150 \pm 20$ & $74 \pm 4$ \\
\hline T311A & $3 \cdot 4 \pm 0 \cdot 3$ & $3 \cdot 7 \pm 0 \cdot 6$ & $33 \pm 2$ & $3 \cdot 8 \pm 0 \cdot 6$ & $189 \pm 10$ & $113 \pm 15$ & $89 \pm 3$ \\
\hline KLT-AAA & $26 \cdot 0 \pm 2 \cdot 3^{*}$ & $10 \pm 1^{*}$ & $20 \pm 2^{*}$ & $2 \cdot 0 \pm 0 \cdot 2$ & $68 \pm 4^{*}$ & $157 \pm 21$ & $96 \pm 4^{*}$ \\
\hline$\Delta \mathrm{KLT}$ & $18 \cdot 0 \pm 1 \cdot 2^{*}$ & $20 \pm 1^{*}$ & $7 \pm 2^{*}$ & $61 \pm 5^{*}$ & $34 \pm 7^{*}$ & $185 \pm 30$ & $72 \pm 3$ \\
\hline \multicolumn{8}{|c|}{ Mutation in C-terminus of $\mathrm{IC}_{3}$ loop } \\
\hline R325A & $4 \cdot 2 \pm 0 \cdot 4$ & $17 \pm 1^{*}$ & $27 \pm 2$ & $27 \pm 3^{*}$ & $247 \pm 32$ & $216 \pm 34$ & $24 \pm 1^{*}$ \\
\hline $\mathrm{K} 328 \mathrm{~A}$ & $2 \cdot 7 \pm 0 \cdot 2$ & $33 \pm 4^{*}$ & $26 \pm 2$ & $30 \pm 2^{*}$ & $201 \pm 34$ & $284 \pm 39$ & $54 \pm 3^{*}$ \\
\hline R325A-K328A & $8 \cdot 7 \pm 0 \cdot 3^{*}$ & $49 \pm 3^{*}$ & $9 \pm 1^{*}$ & $550 \pm 35^{\star}$ & $22 \pm 5^{\star}$ & - & - \\
\hline \multicolumn{8}{|l|}{ Combined mutations } \\
\hline KLT-AAA R325A-K328A & $37 \cdot 7 \pm 1 \cdot 5^{\star}$ & $43 \pm 3^{*}$ & $5 \pm 1^{*}$ & - & $6 \pm 2^{*}$ & $314 \pm 57$ & $25 \pm 2^{*}$ \\
\hline$\Delta$ KLT R325A-K328A & $26 \cdot 1 \pm 1 \cdot 5^{\star}$ & $47 \pm 3^{*}$ & - & - & $7 \pm 2^{*}$ & - & - \\
\hline
\end{tabular}

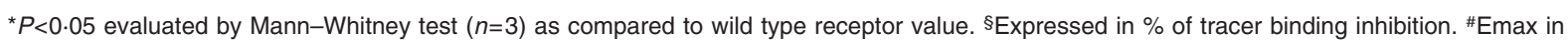
response to $1 \mu \mathrm{M}$ VIP expressed in over basal production of cAMP/min/mg protein. ${ }^{\circ}$ Emax in response to $10 \mu \mathrm{M}$ VIP expressed in $\%$ of digitonin response. Results expressed as means \pm S.E.M. of three independent experiments in duplicate.

\section{$[\mathrm{Ca} 2+]_{\mathrm{i}}$ increase}

VIP induced $[\mathrm{Ca} 2+]_{\mathrm{i}}$ increase was evaluated by a functional assay based on the luminescence of aequorin/coelenterazine following $[\mathrm{Ca} 2+]_{\mathrm{i}}$ increase. As mentioned before, $\mathrm{VPAC}_{2}$ receptors display efficient $[\mathrm{Ca} 2+]_{i}$ increase in presence of Ga16 only. All mutants tested were thus stably transfected in CHO cells expressing constitutively the Ga16 protein. No significant differences in VIP potency $\left(\mathrm{EC}_{50}\right.$ values $)$ were observed between wild type $\mathrm{VPAC}_{2}$ receptor and all the mutants that elicited a $[\mathrm{Ca} 2+]_{\mathrm{i}}$ increase allowing $\mathrm{EC}_{50}$ determination (Table 1 and Fig. 2). In all cases, VIP concentrations required for half-maximal $\left[\mathrm{Ca}^{2+}\right]_{\mathrm{i}}$ increase were higher than that required for adenylate cyclase activation. This has been regularly observed in that system as $\left[\mathrm{Ca}^{2+}\right]_{\mathrm{i}}$ measurement is performed within $20 \mathrm{~s}$ after agonist addition and thus essentially reflects the association constant rate of the ligand rather than the equilibrium constant (Blanpain et al. 1999, Detheux et al. 2000). The K309A, L310A, T311A and $\Delta$ KLT mutants were also undistinguishable from the wild type receptor with respect to the maximal stimulatory effect of VIP. Maximal VIP response was higher in the KLT-AAA mutant (increase of $17 \%$ as compared with wild type receptor) and significantly lowers in R325A, K328A and KLT-AAA R325A-K328A mutants (decrease of $70 \%, 35 \%$ and $70 \%$ respectively). No $[\mathrm{Ca} 2+]_{i}$ increase was observed following VIP stimulation of the R325A-K328A and $\Delta \mathrm{KLT}$ R325A-K328A mutants (Table 1 and Fig. 2).

\section{Receptor phosphorylation}

Like most GPCR, $\mathrm{VPAC}_{2}$ receptors undergo rapid phosphorylation, desensitization and internalization following agonist exposure. Receptor phosphorylation was evaluated after preincubation of the cells with inorganic $\left[{ }^{32} \mathrm{P}\right]$ followed by VIP stimulation and receptor immunoprecipitation with anti- $\mathrm{VPAC}_{2}$ receptor $\mathrm{mAb}$. In a first set of experiments we characterized the wild type $\mathrm{VPAC}_{2}$ receptor phosphorylation by performing time course and dose-effect studies (Fig. 3). VIP induced a rapid, dose-dependent stimulation of $\left[{ }^{32} \mathrm{P}\right]$ incorporation into a protein of an apparent molecular size of $65 \mathrm{kDa}$ that immunoprecipitated with the $\mathrm{VPAC}_{2}$ monoclonal antibody. This band was not observed in control cells that do not express the human $\mathrm{VPAC}_{2}$ receptor (data not shown). The time course of $\mathrm{VPAC}_{2}$ receptor phosphorylation was belt-shaped reaching a maximum after $5 \mathrm{~min}$ treatment with $1 \mu \mathrm{M}$ VIP. VPAC V $_{2}$ receptor phosphorylation was undetectable in absence of VIP. A dose related study performed after 5 min incubation with VIP indicated a progressive increase in receptor phosphorylation up to $1 \mu \mathrm{M}$ VIP. We next evaluated the effect of PKA and PKC inhibitors on $\mathrm{VPAC}_{2}$ receptor phosphorylation by pre-treating cells for $2 \mathrm{~h}$ with $10 \mu \mathrm{M}$ Rp-8-Br-cAMP or $300 \mathrm{nM}$ calphostin. As shown in Fig. 3 no significant differences were observed in $\mathrm{VPAC}_{2}$ receptor phosphorylation following these pre-treatments (evaluated densitometry in arbitrary units: $44615 \pm 3054$ (VIP); $36879 \pm 3578$, $P=0.57$ (VIP+Rp-8-Br-cAMP); $37824 \pm 4534 P=0.31$ 
(VIP+calphostin)) indicating that it was essentially an agonist-dependant phenomenon.

Following 5 min treatment with $1 \mu \mathrm{M}$ VIP, K309A, L310A, T311A mutants exhibited receptor phosphorylation levels similar to that of wild type receptor (Fig. 4). Stimulation of cells expressing KLT-AAA and $\triangle$ KLT mutants results in an increase of receptor phosphorylation levels $(6-$ and 5 -fold as measured by densitometry in arbitrary units on gels loaded with the same amount of protein: $254290 \pm 27855, \quad P=0.028$ (KLT-AAA);
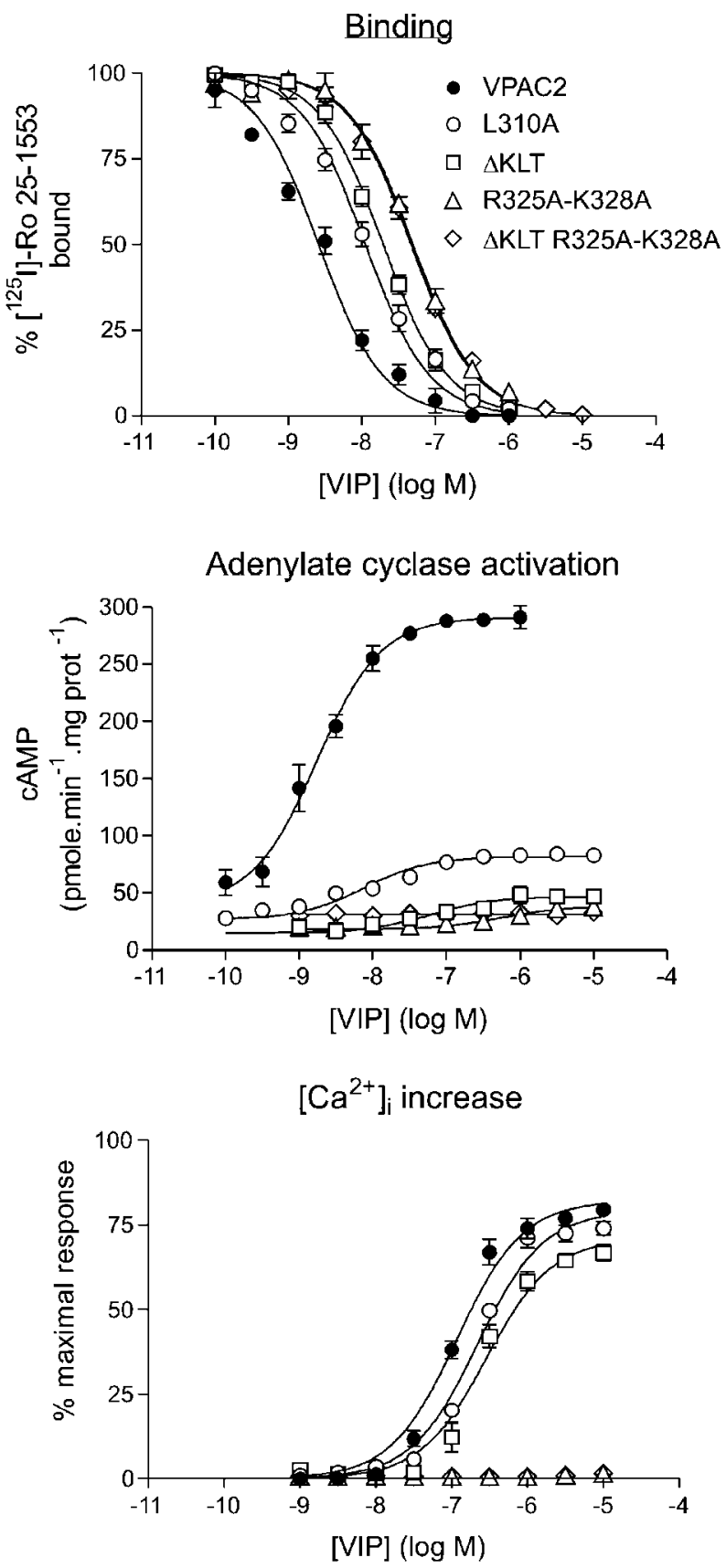

Journal of Molecular Endocrinology (2005) 34, 405-414
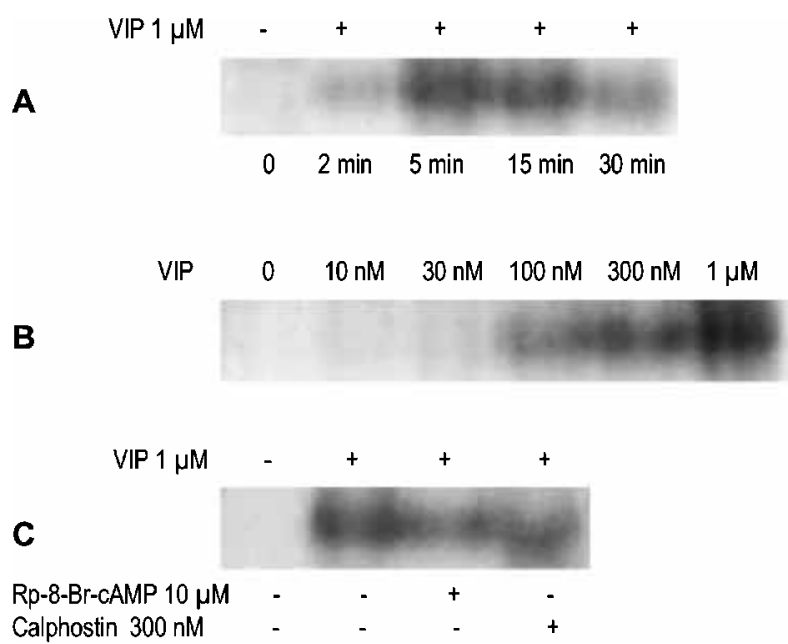

Figure 3 VIP induced phosphorylation of $\mathrm{VPAC}_{2}$ receptor. Receptor phosphorylation levels evaluated after preincubation of the cells with inorganic [ $\left.{ }^{32} \mathrm{P}\right]$ followed by VIP stimulation and receptor immunoprecipitation with anti-VPAC ${ }_{2}$ receptor $m A b$.

(A) Time course study following $1 \mu \mathrm{M}$ VIP stimulation. (B) Dose-effect study following 5 min VIP stimulation. (C) Effect of $2 \mathrm{~h}$ preincubation with $\mathrm{Rp}-8-\mathrm{Br}-\mathrm{cAMP} 10 \mu \mathrm{M}$ and calphostin $300 \mathrm{nM}$ on receptor phosphorylation induced by $5 \mathrm{~min}$ stimulation with $1 \mu \mathrm{M}$ VIP. Representative of three independent experiments.

$209892 \pm 2444, P=0 \cdot 028(\Delta \mathrm{KLT}))$, but as mentioned before the two clones studied express high receptor density, and phosphorylation appeared comparable to that of the wild type receptor when normalized to the amount of receptors. Cells expressing the R325A and K328A mutants displayed a comparable 50\% reduced phosphorylation level (evaluated densitometry in arbitrary units: $21193 \pm 787, \quad P=0.028 \quad$ (R325A); $22493 \pm 1641, P=0 \cdot 028$ (K328A)). Receptor phosphorylation was undetectable following stimulation of the R325A-K328A double mutant (evaluated densitometry in arbitrary units: $640 \pm 165, P=0 \cdot 028)$. Surprisingly, the levels of unstimulated (basal) phosphorylation of KLT-AAA R325A-K328A and $\Delta$ KLT R325A-K328A mutants were significantly higher than those of the wild type receptor or of the mutant expressing large amount of receptors, and were not increased in the presence of VIP (evaluated densitometry basal levels in arbitrary units: $1060 \pm 100\left(\mathrm{VPAC}_{2}\right) ; 6043 \pm 500$ (KLT-AAA);

Figure 2 Pharmacological characterization of $\mathrm{VPAC}_{2}$ wild type receptor and L310A, $\triangle \mathrm{KLT}, \mathrm{R} 325 \mathrm{~A}-\mathrm{K} 328 \mathrm{~A}$ or $\triangle \mathrm{KLT}$ R325A-K328A mutants. VIP competition curves of specific 125I-Ro 25-1553 binding (top panel), dose-effect curves of VIP induced cAMP (middle panel) and [Ca2+] increases (bottom panel) in $\mathrm{CHO}$ cells expressing wild type (close circles), L310A (open circles), $\triangle \mathrm{KLT}$ (open squares), R325A-K328A (open triangles) or $\triangle \mathrm{KLT}$ R325A-K328A (open diamonds) mutants. Results represent the mean of three independent experiments in duplicate. 


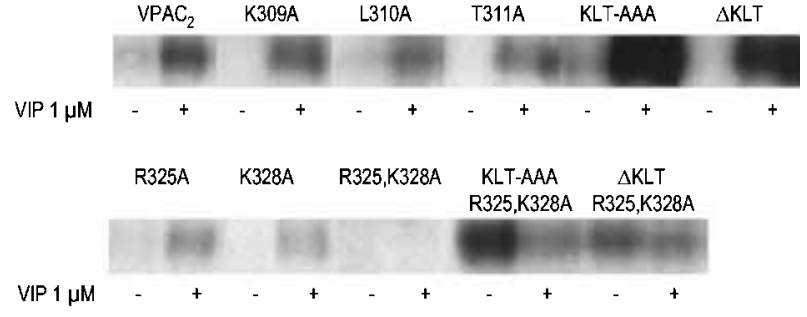

Figure 4 VIP induced phosphorylation of $\mathrm{VPAC}_{2}$ wild type and mutated receptors. Receptor phosphorylation levels evaluated after preincubation of the cells with inorganic [ $\left.{ }^{32} \mathrm{P}\right]$ followed by 5 min stimulation with $1 \mu \mathrm{M}$ VIP and receptor immunoprecipitation with anti-VPAC 2 receptor $m A b$. Representative of three independent experiments.

$1280 \pm 150(\Delta \mathrm{KLT}) ; 114659 \pm 5297, P=0 \cdot 028$ (KLTAAA R325A-K328A); $64678 \pm 7391, P=0.028(\Delta \mathrm{KLT}$ R325A-K328A)). Basal and VIP stimulated receptor phosphorylation of wild type and $\Delta$ KLT R325A-K328A mutant were evaluated in the presence of serine/ threonine kinase inhibitor A3 and tyrosine kinase inhibitor genistein (Fig. 5). Two hour preincubation with $200 \mu \mathrm{M}$ A3 did not modify basal or VIP induced receptor phosphorylation levels of wild type receptor or $\Delta$ KLT R325A-K328A mutant. Two hour preincubation with $100 \mu \mathrm{M}$ genistein reduced VIP stimulated wild type
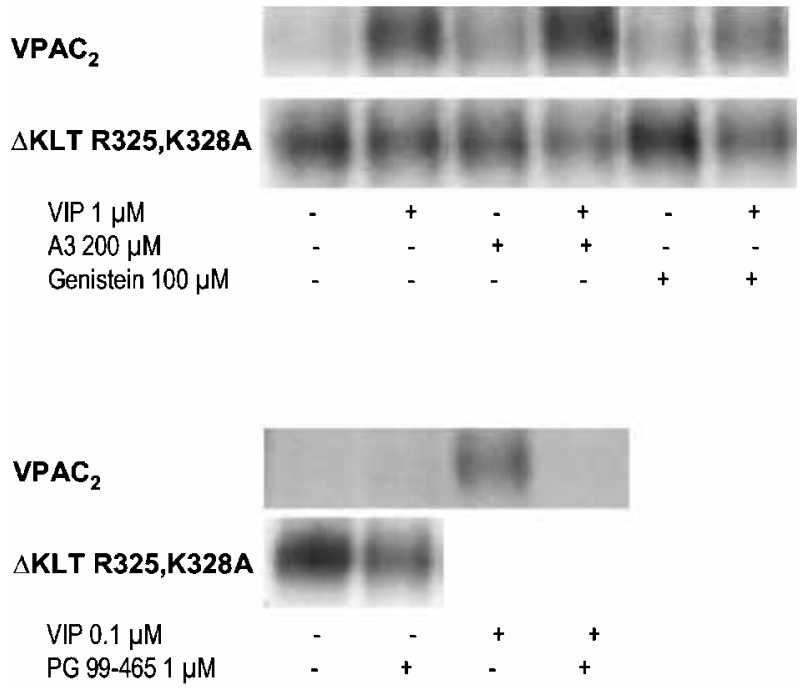

Figure 5 Effect of kinase inhibitors and $\mathrm{VPAC}_{2}$ antagonist on phosphorylation of $\mathrm{VPAC}_{2}$ and $\triangle \mathrm{KLT}$ R325A-K328A receptors. Receptor phosphorylation levels evaluated after preincubation of the cells with inorganic $\left[{ }^{32} \mathrm{P}\right]$ followed by $5 \mathrm{~min}$ stimulation with VIP and receptor immunoprecipitation with anti-VPAC 2 receptor mAb. Top panel, effect of $2 \mathrm{~h}$ preincubation with $\mathrm{A} 3$ $200 \mu \mathrm{M}$ and genistein $200 \mu \mathrm{M}$ on basal or $1 \mu \mathrm{M}$ VIP induced $\mathrm{VPAC}_{2}$ or $\triangle \mathrm{KLT}$ R325A-K328A receptor phosphorylation levels. Bottom panel, effect of 20 min preincubation with $\mathrm{VPAC}_{2}$ antagonist $1 \mu \mathrm{M}$ (PG 99-465) on basal or $0.1 \mu \mathrm{M}$ VIP induced $\mathrm{VPAC}_{2}$ or $\triangle \mathrm{KLT}$ R325A-K328A receptor phosphorylation levels. Representative of three independent experiments.

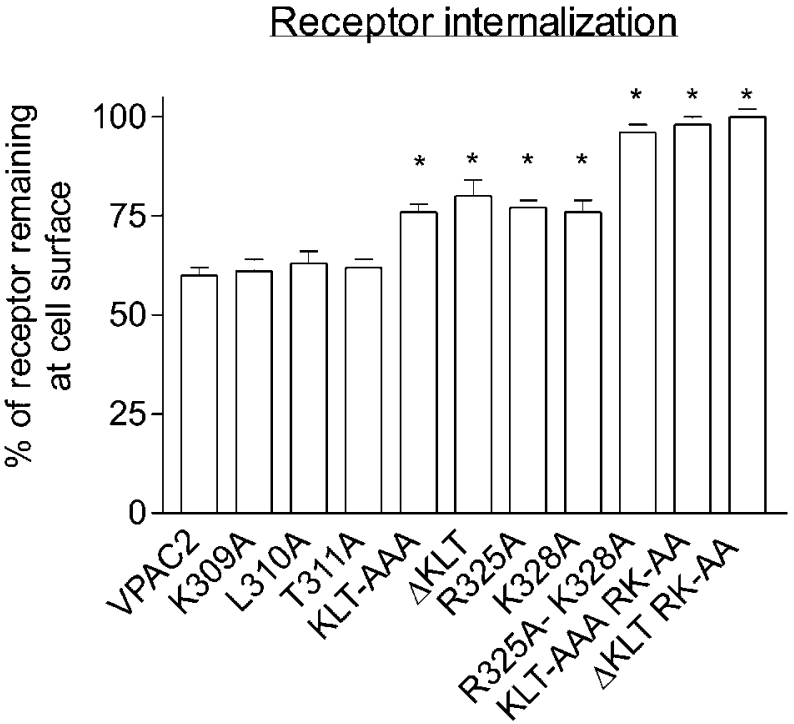

Figure 6 VIP induced internalization of $\mathrm{VPAC}_{2}$ wild type and mutated receptors. Receptor internalization upon $20 \mathrm{~min}$ exposure to $1 \mu \mathrm{M}$ VIP assessed by flow cytometry analysis on viable non-permeabilized cells using anti-VPAC 2 receptor antibody. The results are expressed as percent of receptors remaining accessible to the antibody (mean \pm S.E.M., $n=3$ ). ${ }^{\star} P<0.05$ as compared to wild type receptor response evaluated by Mann-Whitney test.

receptor phosphorylation levels (evaluated densitometry in arbitrary units: $26789 \pm 2871, P=0 \cdot 028)$ but not the basal or VIP stimulated $\Delta$ KLT R325A-K328A receptor phosphorylation levels. The effect of the $\mathrm{VPAC}_{2}$ receptor antagonist PG 99-465 (Moreno et al. 2000) was also evaluated; it did not affect basal phosphorylation, but inhibited the VIP stimulation of the wild type receptor (evaluated densitometry in arbitrary units: $978 \pm 100, P=0 \cdot 028)$, and had a slight inhibitory effect on the basal phosphorylation levels of $\triangle \mathrm{KLT}$ R325AK328A mutant (evaluated densitometry in arbitrary units: $51140 \pm 3218, P=0 \cdot 028$ ) (Fig. 5).

\section{Receptor internalization}

Receptor internalization upon 20 min exposure to $1 \mu \mathrm{M}$ VIP was assessed by flow cytometry analysis on viable non-permeabilized cells using anti-VPAC ${ }_{2}$ receptor antibody. The results are presented in Fig. 6 and are expressed as percent of receptors remaining accessible to the antibody at the cell surface. Following VIP stimulation, K309A, L310A, T311A mutants and the wild type receptor had a comparable $40 \%$ reduction in the number of receptors. KLT-AAA, $\Delta$ KLT, R325A and $\mathrm{K} 328 \mathrm{~A}$ mutants displayed reduced receptor internalization as VIP treatment reduced the number of accessible receptors by 20-25\%. Receptor disappearance was not detected after VIP treatment of cell lines 
expressing R325A-K328A, KLT-AAA R325A-K328A and $\triangle$ KLT R325A-K328A mutants.

\section{Discussion}

The current model of seven transmembrane receptor activation and paradigm of receptor regulation have essentially been developed on the basis of extensive study of the largest family of GPCRs also called the GPCR-A/rhodopsin family (Ferguson 2001, Kohout \& Lefkowitz 2003, Perry \& Lefkowitz 2002, Wess 1997). The mechanisms regulating the GPCR-B family signal transduction are less precisely understood due in part to the size and relative fragility of the ligands and in part to the absence of reliable receptor modelling. As all members of the GPCR-B family, $\mathrm{VPAC}_{2}$ receptor is preferentially coupled to Gas protein that stimulates adenylate cyclase activity and induces cAMP increase (Harmar et al. 1998). We also demonstrated that, in presence of $\mathrm{Ga} 16, \mathrm{VPAC}_{2}$ receptor may couple efficiently to $\mathrm{IP}_{3} /[\mathrm{Ca} 2+]_{\mathrm{i}}$ pathway (Langer et al. 2002). A common feature of the GPCR-B family is the presence of two highly conserved amino acid motifs located in $\mathrm{IC}_{3}$ loop: a lysine and leucine residue located at the junction of $\mathrm{TM}_{5}$ and two basic residues located at the junction of $\mathrm{TM}_{6}$. In the present study, we investigate the contribution of those conserved residues $\left(\mathrm{K}^{309}, \mathrm{~L}^{310}\right.$, $\mathrm{T}^{311}, \mathrm{R}^{325}$ and $\mathrm{K}^{328}$ ) in $\mathrm{VPAC}_{2}$ receptor coupling to Gas and Ga16 and subsequent cAMP and intracellular $[\mathrm{Ca} 2+]_{i}$ increases. This led to the discovery of inactivating mutations and these receptors were studied in detail, particularly for receptor phosphorylation and internalization.

The present data demonstrated that the $\mathrm{K}^{309}-\mathrm{L}^{310}$ $\mathrm{T}^{311}$ sequence (and particularly $\mathrm{L}^{310}$ ) located at junction of $\mathrm{TM}_{5}$ and $\mathrm{IC}_{3}$ loop is involved in adenylate cyclase activation but not in Ga16 coupling. The two conserved basic residues located at junction of $\mathrm{TM}_{6}$ and $\mathrm{IC}_{3}$ loop $\left(\mathrm{R}^{325}\right.$ and $\left.\mathrm{K}^{328}\right)$ were involved in both cAMP and intracellular $[\mathrm{Ca} 2+]_{\mathrm{i}}$ increases. Combined mutation of the two basic residues into Alanine (R325A-K328A mutant), inactivated the receptor almost completely: only a slight cAMP increase could still be detected. In order to obtain a completely inactive receptor we combined mutations altering both proximal and distal domains of $\mathrm{IC}_{3}$ loop. This was achieved with the $\Delta \mathrm{KLT}$ R325A-K328A mutant that did not respond to VIP. These results, in line with previous studies performed on other members of the GPCR-B family that identified the proximal domain of $\mathrm{IC}_{3}$ loop as essential for Gas coupling and adenylate cyclase activation (Huang et al. 1996, Takhar et al.1996, Chan et al. 2001, Couvineau et al. 2003), add to the original finding that this domain was not involved in Ga16 triggered $\mathrm{IP}_{3} /[\mathrm{Ca} 2+]_{\mathrm{i}}$ pathway. Additionally we identified that the distal domain of $\mathrm{IC}_{3}$ loop and particularly two basic residues $\left(\mathrm{R}^{325}\right.$ and $\left.\mathrm{K}^{328}\right)$ were involved in Ga16 coupling but also in adenylate cyclase activation. The effect of GTP on VIP affinity was evaluated by measuring the decreased binding of the iodinated agonist Ro 25-1553. GTP ability to reduce agonist binding was inversely related to the affinity of receptor/G protein complex thus reflecting $\mathrm{G}$ protein-coupling. Several mutations (KLT$\mathrm{AAA}, \Delta \mathrm{KLT}, \mathrm{R}^{325} \mathrm{~A}-\mathrm{K}^{328} \mathrm{~A}$ and KLT-AAA $\mathrm{R}^{325} \mathrm{~A}-$ $\mathrm{K}^{328} \mathrm{~A}$ ) significantly reduced GTP effect, suggesting an impaired interaction between the receptor and G protein. Moreover, only the completely inactive mutant $\left(\Delta \mathrm{KLT} \mathrm{R}^{325} \mathrm{~A}-\mathrm{K}^{328} \mathrm{~A}\right.$ ) was insensitive to GTP, indicating that the global measure of GTP effects reflects the coupling of both Gas and Gal6 to the receptor. The junctions of $\mathrm{IC}_{3}$ loop are predicted to be $\alpha$-helical and it is assumed that the correct positioning of charged amino acids plays a crucial role in $G$ protein interaction. However, our results and other data suggest that uncharged residues are also important for $\mathrm{G}$ protein interaction (Kosugi et al. 1993, Kostenis et al. 1997, Greasley et al. 2001). It is possible that $\mathrm{IC}_{3}$ loop junctions activate $G$ protein directly or that they may serve as regions that control the loop conformation. As mutations may change both direct interaction site and secondary structure, it is difficult to define more precisely the mechanisms involved in $\mathrm{IC}_{3}$ loop $/ \mathrm{G}$ protein interactions.

Like most GPCR, $\mathrm{VPAC}_{2}$ receptors was shown to be rapidly phosphorylated, desensitized and internalized following agonist exposure (McDonald et al. 1998). However, the published data are scarce. Since receptor activation and intrinsic agonist activity are important determinants for agonist induced receptor phosphorylation (Ferguson 2001), we evaluated the effect of partial and complete inactivating mutations on receptor phosphorylation and internalization. We found that the $\mathrm{VPAC}_{2}$ receptor undergoes rapid agonist-dependant phosphorylation following VIP exposure. The significant but partial inhibitory effect of genistein and the absence of evidence for implication of cAMP and phorbol esters activated kinase on receptor phosphorylation also suggest the contribution of both tyrosine kinase (the NetPhos program (Blom et al. 1999) predicts three potentially phosphorylable tyrosine residues) and GRK. We found that $G$ protein-coupling-inactivating mutations also reduced both receptor phosphorylation and internalization in a manner that appeared directly linked to the alteration of the Gas and Ga16 coupling. As mutants studied do not affect phosphorylable residues, this suggests that impaired receptor phosphorylation and internalization directly reflect the reduced ability of the mutants to adopt active receptor conformation. These results gave additional findings that secondary coupling to $G$ proteins also significantly contributes to the mechanisms involved in GPCR regulation and 
trafficking. They could also explain results of some studies describing point mutations that impair the single signal transduction pathway (Gas, Gai or Gaq) and do no affect receptor internalization (Couvineau et al. 2003).

Surprisingly, we observed that the completely inactive mutant (AKLT R325A-K328A) had an enhanced basal receptor phosphorylation level that was unchanged in presence of VIP. This increase can not be explained by a higher receptor density of the cell clone studied as the mutant KLT-AAA had a similar receptor density but a barely detectable basal phosphorylation level. Enhanced basal receptor phosphorylation level has only been described for some constitutively active receptors that mimic the active receptor conformation and are therefore substrates for GRK-mediated phosphorylation in absence of agonist (Mhaouty-Kodja et al. 1999, Min \& Ascoli 2000). The $\Delta$ KLT R325A-K328A mutants do not display a constitutively active phenotype: basal cAMP levels are similar to that of wild type receptor (Fig. 2), agonist binding was GTP insensitive (suggesting an impaired coupling to $\mathrm{G}$ proteins) and all cell clones obtained expressed very high receptor density (Table 1) while constitutively active receptors are generally known to be unstable and display low receptor density. As current paradigm of receptor regulation includes uncoupling of GPCR to G proteins following agonist induced receptor phosphorylation (Ferguson 2001, Kohout \& Lefkowitz 2003), we tentatively test the hypothesis that higher basal phosphorylation was responsible for receptor inactivity. We search for a tool that reduces basal phosphorylation levels of the $\Delta \mathrm{KLT}$ R325A-K328A mutant. We evaluated the effect of A3 (serine/threonine kinase inhibitor), genistein (tyrosine kinase inhibitor) and $\mathrm{VPAC}_{2}$ antagonist (PG 99-465) and found that PG 99-465 only was able to slightly reduce basal phosphorylation levels of the mutant. We therefore treated cells expressing $\triangle$ KLT R325A-K328A mutant for $2 \mathrm{~h}$ with $1 \mu \mathrm{M}$ PG 99-465 and measured VIP stimulated adenylate cyclase activity. The activity was however not restored (data not shown). All together, the data suggest that the $\Delta$ KLT R325A-K328A mutant was phenotypically close to a desensitized receptor phosphorylated, uncoupled to $G$ protein and inactive. As kinase inhibitors do not reduce basal phosphorylation levels of $\Delta$ KLT R325A-K328A mutant and that GRK have the unique ability to recognize and phosphorylate their GPCR substrates only in their active conformation (Ferguson 2001, Kohout \& Lefkowitz 2003), it is possible that enhanced basal phosphorylation levels rather reflects a decrease of affinity for phosphatases. Additionally, this inactive mutant also displays apparent impaired receptor internalization suggesting that it also fails to bind to accessory proteins responsible for receptor trafficking. Actual concepts agree that receptor domains necessary for $\mathrm{G}$ protein-coupling and receptor internalization are in part overlapping (Ferguson 2001,
Kohout \& Lefkowitz 2003), but as this mutant does not respond anymore to VIP, it is likely that this effect is mainly due to its impairment to adopt agonist induced active conformation leading to interaction with arrestins.

In conclusion, we identify that: 1$) \mathrm{IC}_{3}$ loop of $\mathrm{VPAC}_{2}$ receptor is involved in $\mathrm{G}$ protein-coupling: the $\mathrm{K}^{309} \mathrm{~L}^{310} \mathrm{~T}^{311}$ sequence located in the amino-domain is essential for Gas but not Ga16 coupling and two basic residues $\left(\mathrm{R}^{325}\right.$ and $\mathrm{K}^{328}$ ) located in carboxyl-domain are essential for both Gas and Ga16 coupling; 2) inactivating mutations reduce both receptor phosphorylation and internalization; 3) impaired receptor phosphorylation and internalization capability is correlated with potency of inactivating mutations and impaired capability of mutants to adopt active receptor conformation.

\section{Acknowledgments}

This work was financially supported by an 'Interuniversity Poles of Attraction Program, Belgian State, Prime Minister's Office, Federal Office for Scientific, Technical and Cultural Affairs' and a grant from the Fonds Lequime-Ropsy. G Langlet is a recipient of a doctoral fellowship from the FRIA (Communauté Française de Belgique). I Langer is 'chargée de recherches' from the Fonds National de la Recherche Scientifique (FNRS), Belgium.

\section{References}

Blanpain C, Doranz BJ, Vakili J, Rucker J, Govaerts C, Baik SS, Lorthioir O, Migeotte I, Libert F, Baleux F, Vassart G, Doms RW \& Parmentier M 1999 Multiple charged and aromatic residues in CCR5 amino-terminal domain are involved in high affinity binding of both chemokines and HIV-1 Env protein. fournal of Biological Chemistry 274 34719-34727.

Blom N, Gammeltoft S \& Brunak S 1999 Sequence and structure-based prediction of eukaryotic protein phosphorylation sites. Fournal of Molecular Biology 294 1351-1362.

Brini M, Marsault R, Bastianutto C, Alvarez J, Pozzan T \& Rizzuto $\mathrm{R} 1995$ Transfected aequorin in the measurement of cytosolic $\mathrm{Ca} 2+$ concentration $([\mathrm{Ca} 2+] \mathrm{c})$. A critical evaluation. Fournal of Biological Chemistry 270 9896-9903.

Chan KY, Pang RT \& Chow BK 2001 Functional segregation of the highly conserved basic motifs within the third endoloop of the human secretin receptor. Endocrinology 142 3926-3934.

Couvineau A, Lacapere JJ, Tan YV, Rouyer-Fessard C, Nicole P \& Laburthe M 2003 Identification of cytoplasmic domains of hVPACl receptor required for activation of adenylyl cyclase. Crucial role of two charged amino acids strictly conserved in class II G protein-coupled receptors. Fournal of Biological Chemistry $\mathbf{2 7 8}$ 24759-24766.

Detheux M, Standker L, Vakili J, Munch J, Forssmann U, Adermann K, Pohlmann S, Vassart G, Kirchhoff F, Parmentier M \& Forssmann WG 2000 Natural proteolytic processing of hemofiltrate $\mathrm{CC}$ chemokine 1 generates a potent $\mathrm{CC}$ chemokine receptor (CCR)1 and CCR5 agonist with anti-hiv properties. foumal of Experimental Medicine 192 1501-1508. 
Fahrenkrug J 1993 Transmitter role of vasoactive intestinal peptide. Pharmacology and Toxicology 72 354-363.

Ferguson SS 2001 Evolving concepts in G protein-coupled receptor endocytosis: the role in receptor desensitization and signaling. Pharmacological Reiewes 53 1-24.

Gomariz RP, Martinez C, Abad C, Leceta J \& Delgado M 2001 Immunology of VIP: a review and therapeutical perspectives. Current Pharmaceutical Design 7 89-111.

Gourlet P, Vertongen P, Vandermeers A, Vandermeers-Piret MC, Rathe J, De Neef P, Waelbroeck M \& Robberecht P 1997 The long-acting vasoactive intestinal polypeptide agonist RO 25-1553 is highly selective of the $\mathrm{VIP}_{2}$ receptor subclass. Peptides $\mathbf{1 8}$ 403-408.

Greasley PJ, Fanelli F, Scheer A, Abuin L, Nenniger-Tosato M, DeBenedetti PG \& Cotecchia S 2001 Mutational and computational analysis of the alpha(lb)-adrenergic receptor. Involvement of basic and hydrophobic residues in receptor activation and $\mathrm{G}$ protein-coupling. Fournal of Biological Chemistry 276 46485-46494.

Harmar AJ, Arimura A, Gozes I, Journot L, Laburthe M, Pisegna JR, Rawlings SR, Robberecht P, Said SI, Sreedharan SP, Wank SA \& Waschek JA 1998 International Union of Pharmacology. XVIII. Nomenclature of receptors for vasoactive intestinal peptide and pituitary adenylate cyclase- activating polypeptide. Pharmacological Reviewes 50 265-270.

Huang Z, Chen Y, Pratt S, Chen TH, Bambino T, Nissenson RA \& Shoback DM 1996 The N-terminal region of the third intracellular loop of the parathyroid hormone (PTH)/PTH-related peptide receptor is critical for coupling to cAMP and inositol phosphate/Ca2+ signal transduction pathways. Fournal of Biological Chemistry 271 33382-33389.

Kohout TA \& Lefkowitz RJ 2003 Regulation of G protein-coupled receptor kinases and arrestins during receptor desensitization. Molecular Pharmacology 63 9-18.

Kostenis E, Gomeza J, Lerche C \& Wess J 1997 Genetic analysis of receptor-Galphaq coupling selectivity. Fournal of Biological Chemistry 272 23675-23681.

Kosugi S, Okajima F, Ban T, Hidaka A, Shenker A \& Kohn LD 1992 Mutation of alanine 623 in the third cytoplasmic loop of the rat thyrotropin (TSH) receptor results in a loss in the phosphoinositide but not cAMP signal induced by TSH and receptor autoantibodies. Fournal of Biological Chemistry $\mathbf{2 6 7}$ 24153-24156.

Langer I, Perret J, Vertongen P, Waelbroeck M \& Robberecht P 2001 Vasoactive intestinal peptide (VIP) stimulates $[\mathrm{Ca}(2+)]_{\mathrm{i}}$ and cyclic AMP in CHO cells expressing Galpha16. Cell Calcium 30 229-234.

Langer I, Vertongen P, Perret J, Waelbroeck M \& Robberecht P 2002 A small sequence in the third intracellular loop of the
VPAC(1) receptor is responsible for its efficient coupling to the calcium effector. Molecular Endocrinology 16 1089-1096.

McDonald TP, Dinnis DM, Morrison CF \& Harmar AJ 1998 Desensitization of the human vasoactive intestinal peptide receptor (hVIP2/PACAP R): evidence for agonist-induced receptor phosphorylation and internalization. Annals of the New York Academy of Sciences $\mathbf{8 6 5}$ 64-72.

Mhaouty-Kodja S, Barak LS, Scheer A, Abuin L, Diviani D, Caron MG \& Cotecchia S 1999 Constitutively active alpha-lb adrenergic receptor mutants display different phosphorylation and internalization features. Molecular Pharmacology 55 339-347.

Min L \& Ascoli M 2000 Effect of activating and inactivating mutations on the phosphorylation and trafficking of the human lutropin/choriogonadotropin receptor. Molecular Endocrinology 14 1797-1810.

Moreno D, Gourlet P, De Neef P, Cnudde J, Waelbroeck M \& Robberecht P 2000 Development of selective agonists and antagonists for the human vasoactive intestinal polypeptide VPAC(2) receptor. Peptides 21 1543-1549.

O'Donnell M, Garippa RJ, Rinaldi N, Selig WM, Simko B, Renzetti L, Tannu SA, Wasserman MA, Welton A \& Bolin DR 2004 Ro 25-1553: a novel, long-acting vasoactive intestinal peptide agonist. Part I: In vitro and in vivo bronchodilator studies. Fournal of Pharmacology and Experimental Therapeutics 279 1282-1288.

Perry SJ \& Lefkowitz RJ 2002 Arresting developments in heptahelical receptor signaling and regulation. Trends in Cell Biology 12 130-138.

Salomon Y, Londos C \& Rodbell M 1974 A highly sensitive adenylate cyclase assay. Analytical Biochemistry 58 541-548.

Stables J, Green A, Marshall F, Fraser N, Knight E, Sautel M, Milligan G, Lee M \& Rees S 1997 A bioluminescent assay for agonist activity at potentially any G- protein-coupled receptor. Analytical Biochemistry 252 115-126.

Takhar S, Gyomorey S, Su RC, Mathi SK, Li X \& Wheeler MB 1996 The third cytoplasmic domain of the GLP-1[7-36 amide] receptor is required for coupling to the adenylyl cyclase system. Endocrinology 137 2175-2178.

Wess J 1997 G-protein-coupled receptors: molecular mechanisms involved in receptor activation and selectivity of G-protein recognition. FASEB Journal 11 346-354.

Received 23 November 2004

Accepted 6 December 2004

Made available online as an

Accepted Preprint 7 December 2004 